\title{
Ecological and Socio Economic Potential of Agroforestry: A Demonstration of Multi-story Agroforestry Practice in North Shewa Zone, Amhara Region
}

\author{
Mesafint Minale*, Hailemariam Fisha, Abeje Tedla, Reta Eshetu \\ Debre Birhan Agricultural Research Center, Debre Birhan, Ethiopia \\ Email address: \\ mesafintminale@yahoo.com (M. Minale) \\ ${ }^{*}$ Corresponding author

\section{To cite this article:} \\ Mesafint Minale, Abeje Tedla, Hailemariam Fisha, Reta Eshetu. Ecological and Socio Economic Potential of Agroforestry: A Demonstration \\ of Multi-story Agroforestry Practice in North Shewa Zone, Amhara Region. Journal of Plant Sciences. Vol. 8, No. 6, 2020, pp. $201-207$. \\ doi: $10.11648 /$ j.jps.20200806.12
}

Received: March 23, 2020; Accepted: April 23, 2020; Published: November 23, 2020

\begin{abstract}
The homestead multistory agroforestry demonstration was conducted at Tarmaber district of North Shewa zone to demonstrate and evaluate model multistory agroforestry practice for its ecological and economic importance for the rural communities of the area. The demonstration in addition aimed to further enhance farmers' knowledge on this new cultivation method before any further adoption. The demonstration study was started in June 2013 as multistory agroforestry practices and established with special and temporal arrangements with three strata. The upper stratum comprised tree components, middle stratum was fruits and the lower stratum was different annual crops. The total area of a demonstration site was 0.045 ha. Persea americana, Rhamnus prinoides, Coffea arabica, Musa paradisiaca, Phaseolus lunatus, Hibisicus sabdariffa and Vigna unguiculata were planted at different time of the lifetime of the study and yield data were collected. The results from this demonstration study showed that, on average $1507 \mathrm{~kg}$ of edible NTFPs harvested per hectare per year. Organic matter and available phosphorus were increased from 1.52 to $2.14 \%$, and 4.26 to $15.98 \mathrm{ppm}$, respectively. In addition, this practice showed higher net present value (NPV) and benefit-cost ratio (B/C) than the two crop land 3537.36 US\$ and 3.3 per ha from these different components. From this study it can be concluded that multistory agroforestry may be ecologically advantageous land use system for sustainable food, biomass production and economic return comparing with conventional agricultural practices. Therefore, future agricultural extension adoption should consider this homegarden agro-forestry practice for sustainable agricultural production and productivity especially in North Shewa areas where this practice is not well known.
\end{abstract}

Keywords: Agroforestry, Home Garden, Food Insecurity and Soil Degradation

\section{Introduction}

One of the most severe challenges faced by decisionmakers in developing countries is how to improve the wellbeing of the poor in rural areas while maintaining a healthy environment [1]. Food insecurity and poverty are undergoing processes that have been hampering livelihoods of the rural poor of many developing countries. Over the last four decades, agricultural production is increasing due to improved management and inputs. However, it is threatened by worsening climatic changes, land degradation, and low diversification. This resulted in the mismatch of demand and supply from agricultural production in the developing countries has seldom matched the needs of the people. Productivity has declined $16 \%$ on the African agricultural lands in the past 50 years. Of the degraded soils, $58 \%$ are in dry lands and $42 \%$ in humid areas [2].

Ethiopia is the second most populated country in Africa. Agriculture is the dominant land use sector contributing about half of the GDP and $90 \%$ of national export earnings [3]. This sector is dominated by smallholders whose farming is considered as the basis for the national economic development [4]. Despite the efforts made to develop Ethiopian agriculture over the years, food insecurity and land 
degradation are the threat to the survival of the nation. Land degradation has thus become a social, economic, political and technical problem [5]. Soil degradation is the most common reason for declining productivity in developing country [6]. This soil degradation affects more the rural poor people, because they are more dependent on annual agricultural crops [5]. Malnutrition and poor diets are the two major factors for disability. One area where diets are widely deficient is in the consumption of fruits and vegetables, which are associated with increased risk of micronutrient deficiencies, heart disease, cancer, and obesity [7]. As a result, [8] recommended that using at least two serving's fruits and three serving's vegetables per day. However, most people in lower income countries do not meet these requirements [9], largely because of affordability constraints. $94 \%$ of the Ethiopian population relies on wood-based and biomass fuel for household energy. Scarcity of firewood has become acute in many parts of the country causing a continuous rise in prices, and thus increasing the economic burden on the household budget [10]. Furthermore, deforestation, accelerated soil erosion, and land degradation are now serious problems in Ethiopia. As a result crop and livestock yields are generally very low. The land use system is associated with the decrease in the size of holdings of arable and grazing lands. The conversion of forest and marginal lands to other land uses resulted in environmental degradation and a serious threat for sustainable agriculture and forestry development [10].

Recently, farm diversification is neglected. The traditional diversification of farmlands for the sustenance of rural community in Ethiopia has largely been abandoned. Monocropping is encouraged to produce more food using high input and single crop farming.

Agroforestry is overlooked and not taken as a solution for food demands and environmental viability. Agroforestry is a dynamic land use system that integrates trees with crops and/or livestock for agricultural landscapes diversification to sustain social, economic, and environmental benefits [11]. It has the potential to contribute to the improvement of rural livelihood through enhancing farm production and income, while protecting the agricultural environment [1]. These technologies were generally developed to solve the problem of soil fertility depletion, food security, shortage of fuelwood, fodder and land degradation [12].

The growing food insecurity and deteriorating livelihood situations call to practice agroforestry, as a best and promising land use practices [2]. Homegarden agroforestry is one of the agroforestry practices experienced by the farming community to produce diverse products and to improve land productivity. This is a common practice in South and southwestern Ethiopia [13]. For centuries it has been known for its diversity, ecosystem balance, sustainability, household food security and rural development of the region [14].
Several case studies conducted in the smallholder farmers in southwestern of Ethiopia showed that home garden agroforestry is practiced for ages and used by the community [14 and 15]. Even though this practice enable to ensure wood and food security in a parcel of land, it is uncommon to practice in central Ethiopia and not well demonstrated. Hence, the establishment and promotion of homegarden agroforestry can be one of the strategies to support the rural community to access food and improve the household income. This study aimed to demonstrate and evaluate the spatial and temporal arrangement of homegarden agroforestry components, diversification and products of homegarden agroforestry.

\section{Material and Methods}

\subsection{Description of the Study Area}

The study was conducted at Armenia kebele, Tarmaber district, North Shewa zone which is located at 9 $9^{\circ} 51^{\prime} 60 \mathrm{~N}$ latitude and $39^{\circ} 49^{\prime} 38^{\prime \prime}$ E longitude with an average elevation of 1981 m.a.s.l (Figure 1). The district is about $220 \mathrm{~km}$ north east of Addis Ababa. The mean annual rainfall ranges 1500 $2000 \mathrm{~mm}$ and the temperature ranges $11-25^{\circ} \mathrm{C}$.

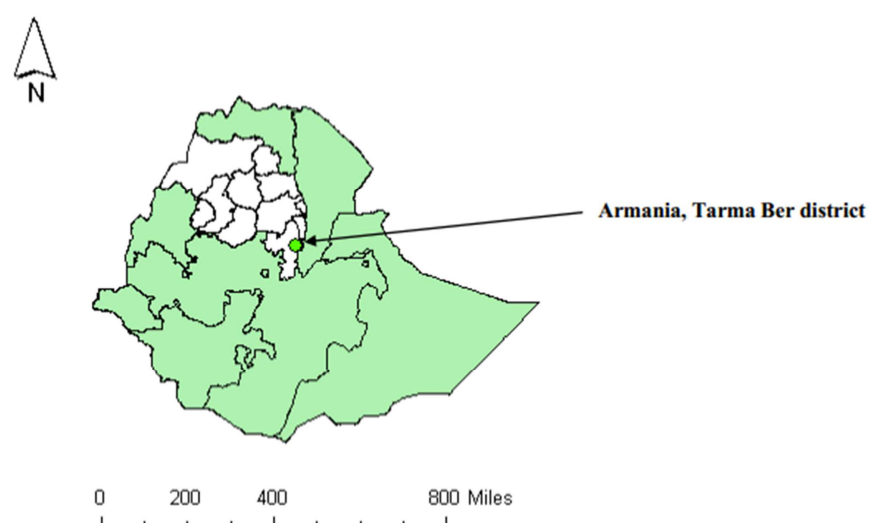

Figure 1. Map of the study site.

The plot size of the homegarden agroforestry was 0.045 ha. Seedlings of the species were raised at the nearby nurseries of the study site. Then species were planted for timber, fruits, and annual crop and/or root tubers in three strata (the upper, middle and lower). The upper stratum was encompassing tree component planted for timber, live fence and shade for the lower strata. The middle stratum was containing Mango (Mangifera indica), Banana (Musa paradisiaca), Rhamnus (Rhamnus prinoides) and Coffee (Coffea arabica). The lower stratum comprised of annual crops and root tubers including tea (Table 1). Since, the lower stratum components changed every year. Trees and crops were arranged and managed spatially and temporally to optimize products from the homegarden. 
Table 1. Components of the homegarden agroforestry.

\begin{tabular}{llll}
\hline Species Name & Spacing between plant (m) & No. of plant/stand & Uses \\
\hline Grevillea robusta & 1 & 6 & 25 \\
Coffea arabica & 2 & 10 & Timber, live fence \\
Cordia africana & & 3 & Stimulus, Cash \\
Mangifera indica & 4 & 4 & Shade, Timber and Fuel-wood \\
Persea americana & 4 & 2 & Fruit and Cash \\
Rhamnus prinoides & 1.5 & 11 & Fruit and Cash \\
$\begin{array}{l}\text { Musa paradisiaca } \\
\text { Annual crops: Cow pea (Vigna unguiculata), Harricot bean } \\
\text { (Phaseolus vulgaris), Hibiscus (Hibiscus sabdariffa L.) }\end{array}$ & 3 & Flavour drink and Medicine \\
\hline
\end{tabular}

\subsection{Data Collection}

Yields of different component, tree growth parameter (DBH, Height), tree biomass and cost of all yields were collected. Soil samples taken from the stand and adjacent open land were collected during the end of the experiment. Farmers' opinions during field demonstration were incorporated in the analysis.

\section{Data Analysis}

\subsection{Estimation of Biomass and Wood Yield}

Tree density, basal area, above-ground biomass and carbon stock were estimated using a method of [16] that was demonstrated for multistory agroforestry. The diameter at breast height (DBH) and height of each woody plant in the stand was measured using caliper and graduated stick.

Basal area (BA) is the cross-sectional area of a tree estimated at breast height $(1.3 \mathrm{~m})$, which is expressed in $\mathrm{m}^{2}$. Basal area will be calculated using the formula of [17]:

$$
\pi r^{2}=B A
$$

Density (D) is an expression of the numerical strength of a species where the total number of individuals of each species in all the quadrants is divided by the total number of quadrants studied.

$$
\frac{\text { Total number of individuals of a species in all quadrants }}{\text { Total number of quadrants sutdied }}=\mathrm{D}
$$

Allometric equation developed by [18] for wet tropical woody biomass and [19] were used to estimate woody biomass and carbon stock. Values for wood specific density were taken from the global wood density database [20].

$$
\begin{gathered}
\mathrm{WD} * \exp \left(-1.239+1.980 * \ln \left((\mathrm{D})+0.207 *(\ln (\mathrm{D}))^{2}-0.0281 *(\ln \right.\right. \\
\left.(\mathrm{D}))^{3}\right)=\mathrm{ABG}
\end{gathered}
$$

Where; $\mathrm{ABG}=$ above ground biomass of tre $\mathrm{e}^{-1}(\mathrm{~kg}), \mathrm{D}=$ $\mathrm{dbh}(\mathrm{cm})$ and $\mathrm{WD}=$ species-specific wood density in $\mathrm{g} \mathrm{cm}^{-3}$

Yields of NTFPs (Persea americana, Rhamnus prinoides, Coffea arabica, Musa paradisiaca, Phaseolus lunatus, Hibisicus sabdariffa and Vigna unguiculata) and fuel-wood extraction (from pollarding over shade tree) were recorded from the initial of the experiment 2013 to 2019 for seven consecutive years on unit area basis and extrapolated to hectare size (Figure 2 and Table 2).

\subsection{Economic Analysis}

Semi-structured questioner interviewed of farmers was conducted to obtain the data needed for cost-benefit analysis of demonstrated agroforestry and the two crop lands. The two crop lands are potential crop land and marginal crop land. Qualitative analysis was carried out to investigate the economic potential of existing agroforestry systems. For cost benefit analysis, the net present value (NPV) and benefit-cost ratio $(\mathrm{B} / \mathrm{C})$ were calculated and compared following [21] method. The NPV determines the present value of net benefits by discounting the streams of benefits and costs back to the beginning of the base [21 and 22]. The NPV is calculated by the following formula:

$$
\sum_{t=0}^{T} \frac{B t-C t}{(1+r)^{\wedge} t}=\mathrm{NPV}
$$

Where; $\mathrm{Bt}$ is the benefits of production by a cultivation practice, $\mathrm{Ct}$ is the costs of production by a cultivation practice, $t$ is the time, running until the end of the investment at $\mathrm{T}, \mathrm{r}$ is the discount rate.

The $\mathrm{B} / \mathrm{C}$ compares the discounted benefits with discounted costs. $\mathrm{A} \mathrm{B} / \mathrm{C}$ of greater than 1 means the cultivation is profitable; whilst a $\mathrm{B} / \mathrm{C}$ of less than 1 means that it generates losses. The $\mathrm{B} / \mathrm{C}$ is calculated as follows:

$$
\frac{\sum_{\mathrm{t}=0}^{\mathrm{n}} \frac{\mathrm{B}}{(1+\mathrm{r})^{\mathrm{t}}} \sum_{t=0}^{n} \frac{B}{(1+r)^{t}}}{\sum_{\mathrm{t}=0}^{\mathrm{C}} \underset{(1+\mathrm{r})^{\mathrm{t}}}{\mathrm{C}} \sum_{t=0}^{n} \frac{C}{(1+r)^{t}}}=\mathrm{B} / \mathrm{C}
$$

Monetary inputs and outputs were calculated on the basis of the selling or buying price in the nearby villages and adjusted to net present value (NPV) at 10\% discount rate.

\section{Results and Discussion}

\subsection{Stand Structure and Productivity}

Total stand biomass, tree density, basal areas are presented in table 2. Tree density and basal area of demonstrated multistory agroforestry were remarkably higher than the result reported by [23] in Dallo Mena District, South-East Ethiopia; [24 and 15] in Southern Ethiopia. Number of tree in agroforestry could be varying according to total rainfall, altitudes of the farm, availability of moisture for plant without a negative effect on crop growth [14].

Traditional management shade tree in Ethiopia is to reduce tree density and understory vegetation to improve the production 
of coffee while maximizing the use of selected tree species [25], through various management techniques, including selection of tree species with desirable properties [24]. For this reason, only few shade tree species with a greater economic or ecological value (shade) or both dominated the coffee-based agroforestry system (Table 4). The main outputs of the systems were analyzed in the form of fuel-wood, biomass and NTFPs extracted during the 2018/2019and values were pooled (Table 2).

Table 2. Stand characteristics of agroforestry practice.

\begin{tabular}{ll}
\hline Parameters & Values \\
\hline Tree density (tree/ha) & 355.6 \\
Basal area $\left(\mathrm{m}^{2} / \mathrm{ha}\right)$ & 11.1 \\
Fuel-wood extraction $(\mathrm{kg} / \mathrm{ha})$ & 588.9 \\
Tree biomass (ton/ha) & 19.9 \\
Biomass carbon stock (ton/ha) & 9.56 \\
NTFPs collection $(\mathrm{kg} / \mathrm{ha} /$ year) & 1507.0 \\
\hline
\end{tabular}

The non-timber forest products (NTFPs) from homegarden agroforestry practice present a valuable source for household economies, as well as for supplementing the household diet. In average $1507 \mathrm{~kg} / \mathrm{ha} /$ year from edible NTFPs (Persea americana, Rhamnus prinoides, Coffea arabica, Musa paradisiaca, Phaseolus lunatus, Hibisicus sabdariffa and Vigna unguiculata) were collected. The carbon stock potential of the demonstration site was 9.56 ton/ha. Agroforestry has been a part and parcel of tropical food production for millennia [12]. Homegarden agroforestry provide diversified products that can contribute for household food security, carbon sequestration, fuel-wood supply and environmental protection [26]. The significance of diverse shade vegetation in providing products such as fruits, medicine, spices timber/building material, animals (protein), root crops, firewood and other materials, and thereby providing a diversified diet and income for smallholder farmers has been noted by a number of people [27]. The trend of NTFPs yield and level of diversification is indicated in figure 2.

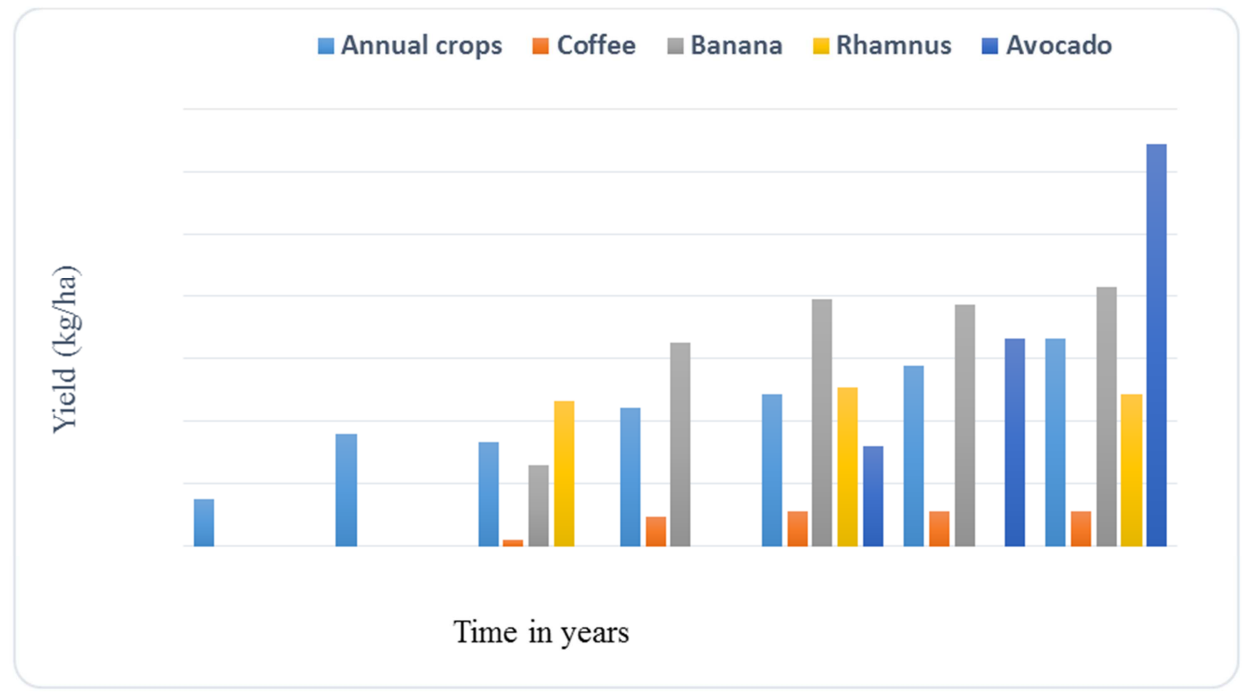

Figure 2. Trend of different products over time after establishment.

\subsection{Structure of Multistory Agroforestry}

The structure of demonstrate agroforestry vegetation can be defined by two components: (i) the horizontal arrangement of species, i.e. the spatial distribution of individuals; and (ii) The vertical arrangement of species i.e. the stratification of vegetation (Figure 3 ).

\subsubsection{Horizontal Structure}

On the basis of planting locations the homegarden species can be divided into 2 categories; species for border only and species for interior only. These include timber tree i.e. Grevillea robusta in border area. In interior part of agroforestry Cordia Africana (Cordia), Musa paradisiaca (Banana), Mangifera indica (Mango), Persea Americana (Avocado), Coffea arabica (Coffee), Rhamnus prinoides (Rhamnus) and annual crops i.e. Phaseolus lunatus (Harricot bean), Hibisicus sabdariffa (Hibisicus) and Vigna unguiculata (Cow pea) which are planted in different years.

\subsubsection{Vertical Structure}

The upper layer of agroforestry consists of different fruit and timber trees such as Cordia africana, Musa paradisiaca and Grevillea robusta from 6 - $10 \mathrm{~m}$ height. Mangifera indica, Persea americana, Rhamnus prinoides and Coffea arabica occupy middle layer from 1.3 - 5m height. Lower layer consists of different annual crops i.e. Hibiscus, Haricot bean, Cow pea which are planted in different years.

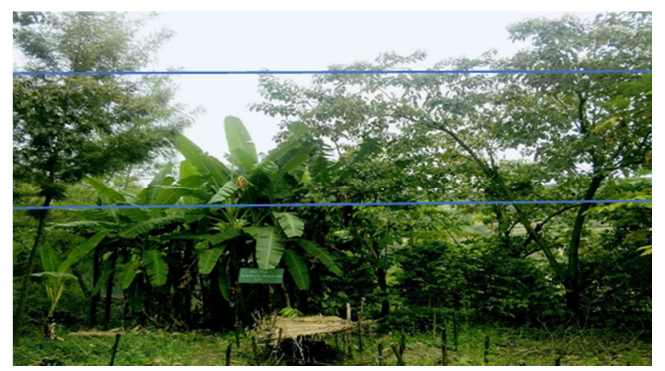

Figure 3. Model multi-strata agroforestry demonstration at Armania kebele. 


\subsection{Soil Nutrient Availability}

Result of soil analysis for demonstrated agroforestry stand and adjacent crop land as control are summarized in Table 3. Slightly changes in soil characteristics were observed after the establishment of agroforestry practices. Organic matter increased 1.52 to $2.14 \%$ due to addition of biomass in the soil. Trees can have a potential to increase organic matter and nutrient status under the canopy as compared to other land uses [28]. Higher organic carbon recorded under the canopy of Cordia africana and Millettia ferruginea than that of open area [24]. Available soil phosphorus was influenced by the practice. Available phosphorus highly increased 4.26 to 15.98 ppm. Higher soil phosphorus level found under the agroforestry practices might be due to high litter accumulation from above and belowground tree biomass. This also increased the soil organic carbon (SOC). As SOC increased, correspondingly the organic phosphorus increased [29]. This practice added substantial amount of available phosphorus due to trees and this result agreed with the other studies [24, 29 and 30]. Similar trends were also reported under Faidherbia albida and Cordia africana on farm lands in Ethiopia [31]. Overall, soil $\mathrm{pH}$ became slightly neutral (6.39 to 6.47), exchangeable Potassium decreased from 1.04 to $0.59 \mathrm{me} / 100 \mathrm{~g}$ soil (Table 3). Soil fertility is said to be maintained in multistory agroforestry in the long-term [12]. The integration of crops, trees, and livestock is a multifunctional production system critical for sustaining farm land in marginal landscapes.

Table 3. Stand soil characteristics and nutrient availability.

\begin{tabular}{|c|c|c|c|c|c|c|c|}
\hline & $\mathrm{pH}(1: 2.5)$ & E.C(dS/m) & EX.K (me/100g) & $\% \mathrm{OC}$ & $\% \mathrm{OM}$ & AV.P(ppm) & T.N (\%) \\
\hline Agroforestry & 6.47 & 0.11 & 0.59 & 1.25 & 2.14 & 15.98 & 0.13 \\
\hline Control (adjacent crop land) & 6.39 & 0.08 & 1.04 & 0.88 & 1.52 & 4.26 & 0.11 \\
\hline
\end{tabular}

\subsection{Cost benefit Analysis}

The economic analysis was carried out for the demonstrated agroforestry, potential and marginal cropland considering the rotation period and the actual number of farmers who have harvested the produce in the past seven years. The result of financial analysis of the three land use systems are presented in table 4. It was revealed that demonstrated multistory agroforestry was more profitable than the two systems because of low cost and high benefit. Profitability measured by net present value (NPV) for agroforestry three and ten times higher than potential and marginal cropland respectively. This is driven by the high output prices of the Cordia africana and Grevillea robusta timber production from this system. Even though agroforestry practices requires some additional costs for rotation.
The major drawback for this model agroforestry practices is reduce the production potential of annual crops where trees compete for use of arable land. And relatively long production period of tree return. Costs and returns of investment emerged critical in determining decisions to plant trees along with tenure security [32]. Improved agroforestry systems can provide a landowner the opportunity to develop short and long term investments that allow for some spreading of financial risk through diversification [33]. Other benefits are higher income throughout the year and better food security. According to [34], who claimed that agroforestry systems were superior land use systems for buffer zones of conservation areas providing income, products, and even environmental services (Table 4). Cost benefits analysis of model multistory agroforestry practice and selected cultivation systems in Armania kebele USD per hectare

Table 4. Cost benefits analysis of model multistory agroforestry practice and selected cultivation systems in Armania kebele USD per hectare.

\begin{tabular}{|c|c|c|c|}
\hline Particulars & Agroforestry & Potential crop land & Marginal crop land \\
\hline Input cost for crops and trees:- Labor, seed, fertilizer, pesticide cost, & 679.80 & 866.64 & 690.03 \\
\hline Return from crops, fruits & 1396.98 & 1507.48 & 819.97 \\
\hline Return from selling timber & 3153.72 & & \\
\hline $\mathrm{NPV}(\mathrm{r}=10 \%)$ & 3537.36 & 1077.60 & 323.12 \\
\hline $\mathrm{B} / \mathrm{C}$ & 3.3 & 1.7 & 1.2 \\
\hline
\end{tabular}

\subsection{Farmers' Attitudes Towards Multistory Agroforestry}

The farmers' positive perception is indicated as an important step in adoption process [35]. The semi structured questionnaire interviews with 25 key informants in Armania kebele farmers revealed some of the factors for adoption multistory agroforestry (Table 5). For majority of the farmers (88\%) multistory agroforestry was a prime source of household income. The other major reason for adoption of agroforestry was food from fruit tree (72\%). Very few farmers contribute to timber for making farm implement and household furniture. Near to half percentage of respondents also mentioned positive attitude towards soil fertility $(48 \%)$ (Table 5).

Table 5. Determinants for adoption of multistory agroforestry.

\begin{tabular}{ll}
\hline Determinants & Percentage \\
\hline Additional income & 88 \\
Fodder & 28 \\
Source of money in emergency & 40 \\
Supply fruit for the homestead & 72 \\
Fuel-wood & 32 \\
Timber & 24 \\
Soil fertility & 48 \\
Provide better Environment & 32 \\
\hline
\end{tabular}


Despite agroforestry systems being more profitable, most farmers in the study area still persist with the less profitable marginal crop land cultivation. The semi structured questionnaire interviews with 25 key informant Armania kebele farmers revealed some of the factors for adoption multistory agroforestry (Figure 4).
The major constraint for the adoption of multistory agroforestry is shortage of water $(80 \%)$ and a long period of time for harvesting $(40 \%)$. This is particular true for study area farmer as their cultivation are largely depend on rain fed and subsistence oriented and yield insufficient to invest on agroforestry.

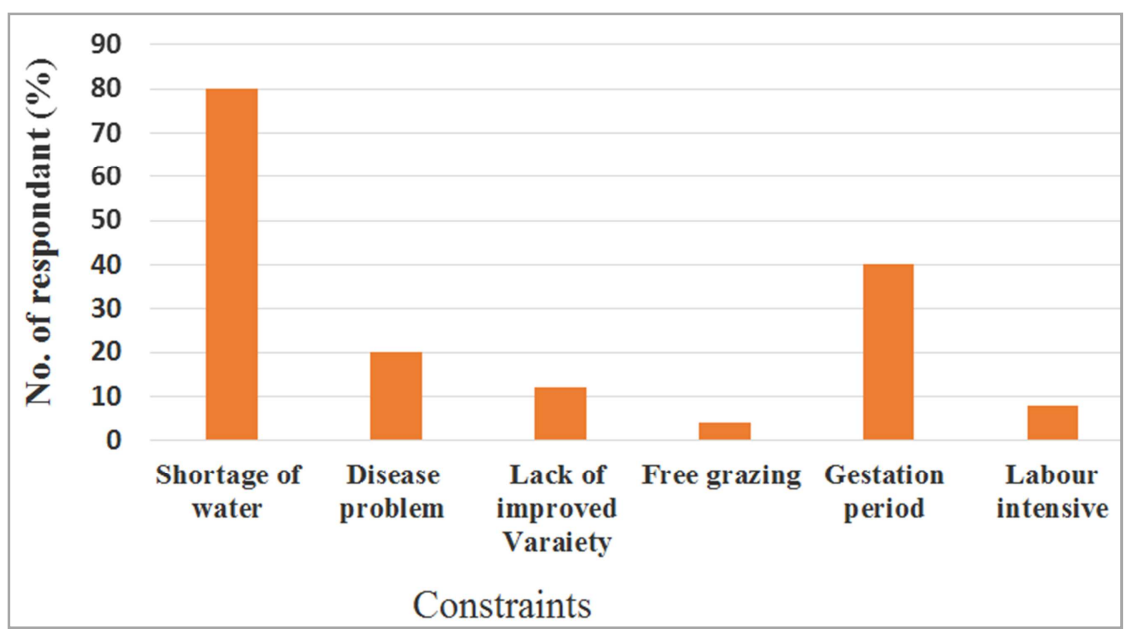

Figure 4. Constraints for adoption of agroforestry practice $(n=25)$.

\section{Conclusion and Recommendation}

Practicing homegarden agroforestry can enhances the livelihood of the farmer by providing socio-economic and rehabilitating the degraded lands. Tree species, play a vital role to improve soil fertility and farmer livelihood. Demonstrated multistory agroforestry have a potential to contribute $20 \%$ of annual average income of Armania farmers. After five years establishment the multistory agroforestry rapidly increased its production but it need intensive management.

Farmers in the study village were willing to adopt the multistory agroforestry practices but they were concerned about shortage of water and give more need for fast growing species. Generally, a well-managed multistory agroforestry can provide food, fodder and fuel-wood for the rural people. The following suggestions are recommended to increase the livelihood of the people.

1) Unused homestead and marginal land is available around most of the households; this land can be converted to multistory agroforestry to meet the demand for timber, fuel-wood, fruit, fodder and raw materials.

2) Increasing the number of fast growing and improved species is important in order to provide early cash return to the farmers.

3) In order to promote sustainable agroforestry to the region, the extension networks with water harvesting techniques at the local level should be strengthened.

\section{Acknowledgements}

This research was supported by Amhara Region Agricultural Research Institute (ARARI)

\section{References}

[1] El-Lakany, H. 2004. Improvement of Rural Livelihoods: the role of Agroforestry. In first world agroforestry congress (Vol. 27, pp. 1-4).

[2] Teija Reyes. 2008. Agroforestry systems for sustainable livelihoods and improved land management in the East Usambara Mountains, Tanzania.

[3] MoFED. 2007. Ethiopia building on progress: a plan for accelerated andsustained development to end poverty Addis Ababa: Ministry of Finance and Economy Development. (Annual progress report).

[4] Djurfeldt, G., Aryeetey, E. \&Isinika, C. A. 2011. African smallholders food cropsmarkets and policy. CPI Antony Rowe.ed. United Kingdom.

[5] Hellin, J. 2006. Better Land Husbandry: From Soil Conservation to Holistic Land Management. Science Publishers, Enfield and Plymouth. 325 p.

[6] Scherr, S. 1999. Soil Degradation: a threat to developingcountry food security by 2020 ? Food, Agriculture and the Environment Discussion Paper 27. International Food Policy Research Institute. Washington D.C. 63 p.

[7] Forouzanfar, M. H., Alexander, L., Anderson, H. R., Bachman, V. F., Biryukov, S., Brauer, M., Murray, C. J. 2015. Global, regional, and national comparative risk assessment of 79 behavioural, environmental and occupational, and metabolic risks or clusters of risks in 188 countries, 1990-2013: a systematic analysis for the Global Burden of Disease Study 2013. Lancet 386 (10010), 2287-2323.

[8] WHO/FAO. 2003. Joint WHO/FAO Expert Consultation on Diet, Nutrition and the Prevention of Chronic Diseases. Joint FAO/WHO Expert Consultation, Geneva. 
[9] Del Gobbo, L. C., Khatibzadeh, S., Imamura, F., Micha, R., Shi, P., Smith, M., Mozaffarian, D. 2015. Assessing global dietary habits: a comparison of national estimates from the FAO and the Global Dietary Database. Am. J. Clin. Nutr. 101 (5), 1038-1046. https://doi.org/10.3945/ajen.114.087403.

[10] Bishaw, B. and A. Abdelkadir. 2003. Agroforestry and community forestry for rehabilitation of degraded watersheds on the Ethiopian highlands. International Symposium on Contemporary Development Issues in Ethiopia, July 11-12, Addis Ababa.

[11] ICRAF. 2002. What Is Agroforestry? World Agroforestry Center, Nairobi.

[12] Kumar B. M. and Nair P. K. R. 2004. The enigma of tropical homegardens. AgroforestSyst 61: 135 - 152.

[13] Okigbo, B. N. 1990. Homegarden in tropical Africa. In: Landauer, K. (Ed.) International workshop in HomegardenIndonesia United Nation university press.

[14] Abebe, T., Wiersum, K. F., Bongers, F. J. J. M., \& Sterck, F. 2006. Diversity and dynamics in homegardens of southern Ethiopia. In Tropical homegardens (pp. 123-142). Springer, Dordrecht.

[15] Tesemma, M. N. 2013. The indigenous agroforestry systems of the south-eastern Rift Valley escarpment, Ethiopia: Their biodiversity, carbon stocks, and litter fall (Doctoral dissertation, University of Helsinki).

[16] Tolera, M., Asfaw, Z., Lemenih, M., \& Karltun, E. 2008. Woody species diversity in a changing landscape in the southcentral highlands of Ethiopia. Agriculture, ecosystems \& environment, 128(1-2), 52-58.

[17] Philip, M. S. 1994. Measuring trees and forests. CAB international.

[18] Chave J., Andalo C., Brown S., Cairns M. A., Chambers J. Q., Eamus D., Fölster H., Fromard F., Higuchi N., Kira T., Lescure J.-P., Nelson B., Ogawa H., Puig H., Riéra B. \&Yamakura T. 2005. Tree allometry and improved estimation of carbon stocks and balance in tropical forests. Oecologia 145:87-99.

[19] IPCC. 2006. IPCC Guidelines for National Greenhouse Gas Inventories. In H. S. Eggleston, L. Buendia, K. Miwa, T. Ngara\& K. Tanabe (Eds.), IPCC National Greenhouse Gas Inventories Programme Institute for Global Environmental Strategies, Japan.

[20] Zanne A. E., Lopez-Gonzalez G., Coomes D. A., Ilic J., Jansen S., Lewis S. L., Miller R. B., Swenson N. G., Wiemann M. C., Chave J. 2009. Data from: towards a worldwide wood economics spectrum, Dryad Digital Repository, Global Wood Density Database, Retrieved from: http://dx.doi.org/10.5061/dryad.234 (accessed on December $26,2014)$.

[21] Stocking M, Bojo J, Abel N. 1990. Financial and economic analysis of agroforestry: key issues. In: Prinsley RT (ed) Agroforestry for sustainable production: economic implications. The Commonwealth Secretariat, London, pp 13119.
[22] Disney SM, Warburton RDH, Zhong CQ.2013.b Net present value analysis of the economic production quantity. $J$ Manag Math 24:423-435.

[23] Mengistu, B., \& Asfaw, Z. 2016. Woody species diversity and structure of agroforestry and adjacent land uses in Dallo Mena District, South-East Ethiopia. Natural Resources, 7(10), 515.

[24] Asfaw Z. 2004. Tree species diversity, top soil condition and arbusecular mycorrhizal association in the Sidama traditional agroforestry land use, Southern Ethiopia. Doctoral Thesis, Swedish University of Agricultural Science.

[25] Aerts R., Hundera K., GezahegnBerecha, Gijbelsc P., Baeten M., Van Mechelena M., Hermya M., Muysa B. and Honnay O. 2011. Semi-forest coffee cultivation and the conservation of Ethiopian Afromontane rain forest fragments. Forest Ecology and Management 261:1034-1041.

[26] Nair PKR, Nair VD, Kumar BM, Showalter JM. 2010. Carbon sequestration in agroforestry systems. AdvAgron 108:237-307

[27] Peeters, L. Y., Soto-Pinto, L., Perales, H., Montoya, G., \& Ishiki, M. 2003. Coffee production, timber, and firewood in traditional and Inga-shaded plantations in Southern Mexico. Agriculture, ecosystems \& environment, 95(2-3), 481-493.

[28] Young A., 1997. Agroforestry for soil management $2^{\text {nd }}$ ed. $\mathrm{CAB}$ international in association with the international centre for research in agroforestry Nairobi, Kenya. p 45.

[29] Wolle, H. S., Lemma, B., \& Mengistu, T. 2017. Effects of ZiziphusSpina-Christi (L.) on Selected Soil Properties and Sorghum Yield in Habru District, North Wollo, Ethiopia. Malaysian Journal of Medical and Biological Research, 4(2), 61-68.

[30] Tedla, A. and Asfaw Z. 2018. Effect of Acacia nilotica on selected soil properties, sorghum and teff yield in parkland agroforestry, Kewot district, Amhara, Ethiopia. Berhan International Research Journal of Science and Humanities, 2(1), 114-139.

[31] Yadessa, A., Itanna, F., \& Olsson, M. 2009. Scattered trees as modifiers of agricultural landscapes: the role of waddeessa (Cordia africana Lam.) trees in Bako area, Oromia, Ethiopia. African journal of ecology, 47, 78-83.

[32] Duguma LA, 2013. Financial analysis of agroforestry land uses and its implications for smallholder farmers livelihood improvement in Ethiopia. AgroforSyst 87:217-231.

[33] Hoekstra, D. A. 1987. Economics of agroforestry, Agroforestry Systems 5(3):293-300

[34] Murniaty, D. P. Garrity, A. Ng. Gintings. 2001. The contributions of agroforestry systems to reducing farmers' dependence on the resources of adjacent national parks: a case study from Sumatra, Indonesia. Agroforestry Systems 52(3): 171-184.

[35] Franzel S, Phiri D, Kwesiga F. 2002. Assessing the adoption potential of improved fallows in eastern Zambia. In: tree on thefarm: assessing the adoption potential of agroforestry practices in Africa (S. Franzel and S. J. Scherr Eds.), CAB International, Walling ford, UK. 